\title{
The Bigger, the Better: Coalitions in the GATT/WTO*
}

\author{
Gabriel Cepaluni, Manoel Galdino and Amâncio Jorge de Oliveira \\ Center for International Negotiations Studies (Caeni), University of São Paulo
}

\begin{abstract}
What does it take to make a coalition successful? Bigger coalitions are more likely to be successful because the GATT/WTO is a consensus-based institution and countries are informally penalized if they isolate themselves. Through a Bayesian statistical analysis, the article corroborates the above hypothesis. To further investigate the research question, qualitative case studies of the G-10 in the Uruguay Round and the Public Health Coalition in the Doha Round are conducted. These cases show that the more convincing the framing of a position, the better are the chances of coalitions keeping a large number of followers and supporters, thereby affecting their odds of success. By building a unique database and applying a new research design to the topic, the study rigorously tests theories about coalitions that had previously only been proposed but not empirically analyzed.
\end{abstract}

Keywords: international coalitions, bayesian analysis, multilateralism, economic openness, international negotiations

\section{Introduction}

oalitions are a pervasive feature of both domestic and global politics. Class struggles, interests groups, oligopolies, and alliances are all forms of coalitions. Many

Previous versions of this paper were presented at the IPSA-ECPR Joint Conference in São Paulo, 2011, at the Associação Brasileira de Relações Internacionais (ABRI), 2011, and at several seminars at the Centro de Estudos das Negociações Internacionais (Caeni) at the University of São Paulo (USP). The authors are especially grateful to Clara Brandi, Po-Kuan Wu, Eiiti Sato, Maria Izabel Valladão de Carvalho, Adriana Schor, Janina Onuki, Paolo Ricci, Maria Antonieta Del Tedesco Lins, Cristiana Carneiro, Andrew Bennett, Robert Wolfe, James Vreeland, James Hollyer, Ernesto Calvo, Erik Voeten, Marc Busch, Joanne Gowa, and Guy Whitten. 
social scientists have gained prominence by theorizing about these topics. The General Agreement on Tariffs and Trade (GATT) and the World Trade Organization (WTO) are also fundamental institutions responsible for regulating international trade. In the field of international relations, there is an enormous literature on various aspects of the GATT/ WTO: the dispute settlement mechanism (Bown 2004; Busch 2000; Busch and Pelc 2009, Busch and Reinhardt 2001, 2006; Busch, Reinhardt, and Shaffer 2009; Charnovitz 2001, Davis and Bermeo 2009; Davis and Shirato 2007; Kim 2008; Moon 2006; Pelc 2010; Reinhardt 2001; Rosendorff 2005; Smith 2004; Wolfe 2005; Zangl 2008;), the effects of the GATT/WTO on international trade (Goldstein, Rivers, and Tomz 2007; Rose 2004; Subramanian and Wei 2007), the overlapping role of the GATT/WTO and other preferential trade agreements (Busch 2007; Haftel 2004; Mansfield and Reinhardt 2003, 2008), and the effects of the WTO's decision-making rules (Steinberg 2002; Tijmes-LHL 2009). However, studies on coalitions in the GATT/WTO are in their infancy. Moreover, most authors who research this topic use a single or few case studies as their sole methodology. This article innovates in terms of both methodology and substance.

We use a mixed-method approach to conduct our research. We analyze 31 cases of international coalitions through a Bayesian statistical analysis to find out the main variables associated with coalitions' successes and failures in GATT/WTO negotiations. To make our results more robust, we use a within-case study design to reveal possible causal mechanisms behind our quantitative findings. We investigate the outcome of two intellectual-property-rights coalitions: the G-10 at the Uruguay Round (1986-1994) and the Public Health Coalition at the beginning of the Doha Round (2001-). Both coalitions are large. However, the G-10 is a broad-based coalition that failed in GATT/WTO negotiations, while the Public Health Coalition is an issue-based group considered an example of success at the beginning of the Doha Round.

The main goal of this study is to understand which type of coalition is more successful in the GATT/WTO negotiations. There are some controversies as to whether issue-based coalitions are more successful than broad-based ones. Similarly, different authors debate whether coalitions with large numbers of participants are more conducive to successful outcomes in GATT/WTO negotiations. Our main statistical finding is that large coalitions are more likely to succeed. Issue-based coalitions are also more successful, but this finding is not statistically robust. Complementing our qualitative findings, our case studies suggest the following causal mechanism: since GATT/WTO negotiations are ruled by consensus, the bigger the coalition, the higher the chances of succeeding. Issue-based coalitions with a convincing message framing hold their members together, keeping the coalition large and consequently affecting its odds of success. Negotiators probably can design issue-based coalitions by selecting the issue they want to fight for. Convincing frames, on 
the other hand, are both dependent on the strategies envisioned by coalition members and contingent on how others react to the messages put forth and defended by the coalition.

\section{Collective Action}

Mancur Olson argues that there is a systematic tendency for exploitation of the great by the small in relation to the payment of collective benefits: "The larger a group is, the farther it will fall short of obtaining an optimal supply of any collective good, and the less likely it will act to obtain even a minimal amount of such a good. In short, the larger the group, the less it will further its common interests" (Olson 1965, 36). Debating whether larger groups can be successful in acting together and furthering their interests has been a hallmark of studies on collective action for more than four decades (Buchanan 1965; Chamberlin 1974; Esteban and Ray 2001; Frohlich and Oppenheimer 1970; Hardin 1968, 1982; McGuire 1974; Oliver and Marwell 1988; Olson 1971, 1982; Ostrom 1990, 2000; Pecorino 2009; Pecorino and Temimi 2008). According to Riker's "size principle," "with complete and perfect information, winning coalitions tend toward the minimal winning size" (Riker 1970, 305). In situations similar to "n-person, zero-sum games with side-payments, participants create coalitions just as large as they believe will ensure winning and no larger" (Riker 1962, 32).

Olson and Zeckhauser use the examples of NATO and the UN to support their general theory of collective action (Olson and Zeckhauser 1966). According to the authors, the United States and other major members have borne a disproportionate cost to promote the common defense interests of NATO states. Moreover, the smaller members of NATO devote much lower percentages of their incomes toward that common goal. The authors concluded that the UN tends to encourage major industrialized nations to bear disproportionate costs for the maintenance of the institution relative to the least-developed countries. In NATO, this is also because each ally enjoys only a fraction of the collective benefits but bears the costs of any additional amount of these public goods. This means that individual members of a coalition have an incentive to stop providing the collective benefit before the optimal quantity of this benefit has been provided. This is particularly true for the smaller members, who get smaller shares of the total benefit and have little incentive to provide additional amounts of collective benefits once the larger members have provided the amounts they want for themselves (Ibid., 278).

Several authors adopting a rational-choice framework question the "group size paradox" proposed by Mancur Olson (Chamberlin 1974; Esteban and Ray 2001; Oliver and Marwell 1988; Ostrom 1990, 2000; Pecorino 2009; Pecorino and Temimi 2008). This literature concludes that the "group size paradox" does not hold in many political and 
economic settings. However, there is not a clear consensus on when or why the "group size paradox" does or does not apply.

Esteban and Ray (2001) construct a model where multiple groups compete to obtain a favored policy. A member's contribution to the group effort raises the probability that the group's favored policy will be adopted via a rent-seeking contest among the groups. The main result of the model is that, if the lobbying costs are nonlinear (for instance, the marginal cost of lobbying is increasing and not constant, as it would be the case if it were linear), then lager groups will be on average more successful than smaller ones in lobbying. The result holds due to the assumption that the reward of the lobby activity is not only a pure public or a pure private good, but a mix of both. According to Pecorino and Temimi, "the mechanism identified by Esteban and Ray will be effective in a large group, if the public good in question has a low degree of rivalry". Thus, "being a member of a larger group is advantageous in successfully obtaining political rights" (Pecorino and Temimi 2008, 798). The scenario described by Esteban and Ray is similar to the one we have in this paper since coalitions are groups competing with either other countries (or groups) to further their interests.

Constructivist scholars criticize the mainstream rationalist approach by emphasizing that coalition members share a common identity (Abizadeh 2005; Cerny 1995; Greenhill 2008; Wendt 1992, 1994, 1999). As Wendt (1994) argues, most researchers have assumed that collective action should be analyzed in the framework proposed by Olson, who believed that cooperation between self-interested actors can be promoted by coercion or by selective incentives to individual states. However, the ability to solve collective-action problems also depends on how the identities of social actors influence collective interests. Identification is a continuum on which actors range from total selfishness to loyalty and solidarity. It is possible to analyze collective action not only as a balance between the costs and benefits of cooperation between self-interested actors "but as a process creating of new definitions of self" (Ibid., 387).

The dichotomy between the rationalist and the constructivist worldviews made possible the creation of a dichotomous typology of coalitions in the GATT/WTO negotiations. Pragmatic issue-based coalitions driven by narrow interests and broad-based coalitions driven by ideological reasons are viewed as two ends of a continuum.

A major focus of the literature on the coalitions in the GATT/WTO is the establishment of causal arguments between "type of coalitions" (e.g., issued-based versus broadbased coalitions) and outcome (e.g., success versus failure). Most of the literature argues that issue-based coalitions provide more favorable results in GATT/WTO negotiations (Higgot and Cooper 1990; Narlikar 2003; Odell and Sell 2006; Rothstein 1984). In this literature, the Cairns Group is normally chosen as a bargaining coalition model (Cooper, 
Higgott, and Nossal 1993; Higgot and Cooper 1990). On the other hand, broad-based coalitions tend to be more unstable due to the risk of defection by participants. Hamilton and Whalley $(1988,1989)$ are among the few authors that disagree with this view. They advocated, at the beginning of the Uruguay Round of GATT, that issue-based coalitions tended to be unstable because they would not survive bargaining over multiple issues (Hamilton and Whalley 1989, 555-57). Adopting a constructivist perspective, one can argue that a broad-based coalition could be more effective, since coalition partners may be expected to have preferences that are more similar to one another's than those of participants in issue-based coalitions that may have been formed as the result of a goal-oriented strategy (Narlikar 2003; Narlikar and Tussie 2004).

\section{Question and Hypothesis}

Which types of coalitions are more likely to be successful in GATT/WTO negotiations?

- Hypothesis 1: Coalitions with large numbers of participants are more successful in GATT/WTO negotiations than coalitions with fewer participants.

- Hypothesis 2: Issue-based coalitions are more successful than broad-based groups in GATT/WTO negotiations.

\section{Methodology}

Although studies on coalitions in the GATT/WTO are in their infancy, the literature is maturing. In our research we realized that there is considerable collaboration between many authors studying coalitions in the GATT/WTO. For example, there are books and articles co-authored by researchers from the same network. The "Economic Negotiation Network"1 led by John Odell brings many researchers who write about international coalitions in GATT/WTO negotiations. Consequently, there is also some convergence in terms of methods, especially regarding the use of case studies. A contribution of this paper is that it employs also but not only case studies in its analysis.

To build our database, we used all publications we found on the subject in various search engines: Google Scholar, JSTOR, Ebsco, and Ingenta, among others. We built our database keeping in mind a methodology called meta-analysis. This methodology normally calls for the use of unpublished material, since the bias in favor of published papers that have statistical significance is well known. Thus, the inclusion of unpublished studies would reduce this bias (Stanley 2001). Our choice is less methodological and more related to access to information. As the current literature on the topic consists almost exclusively of qualitative case studies, we do not have any problem with the publication bias related to the statistical significance of these studies. However, as the literature is still expanding, 
many studies are still in the form of working papers. Thus, our database would have less information if it did not include all the published and unpublished materials we could find. ${ }^{2}$ Since our topic has many interacting variables which are very difficult to observe and quantify, we decided to work primarily (but not exclusively) with secondary sources. Primary sources (documents, interviews, newspaper articles) commonly used in case studies are more difficult to organize and interpret.

In Table 1, we analyze the studies that served as references to build our database. In our work, the lack of data is mainly due to the fact that not all studies contained information on the variables we aimed to code. We also decided to adopt the most recent literature in cases of redundant information. Usually, the most updated work adds new empirical data to previous debates and benefits from having a greater historical distance from the events.

Our dependent variable is the result (success or failure) of bargaining involving coalitions. As stated above, the definition of success was based on the literature. We essentially trusted on the experts uncritically. Coding divergent case studies has not been a problem in practice. If it were, we would have coded them as "mixed cases." Our first independent variable is the scope of the coalitions (issue-based versus broad-based groups). In practice, broad-based coalitions are normally developing country groups that want either to block or to hijack the agenda of developed countries in GATT/WTO negotiations. Issue-based coalitions, on the other hand, are more focused and pragmatic groups that seek concessions in specific areas of the negotiations. Our second independent variable is coalition size, calibrated by the number of member states at the moment of coalition formation. Since most coalitions do not formally end, it is easier to count its members when the coalition is formed. As we still have a medium- $N$ database, we preferred to deal with fewer variables in this paper.

Table 1 shows that most of the analyzed studies have used one or a few cases; other authors list other cases but do not quantitatively analyze them. Generally, they give a historical analysis of international coalitions in the GATT/WTO and an appendix with some information about the cases. 
Table 1. Studies on Coalitions in GATT/WTO Negotiations.

\begin{tabular}{|c|c|}
\hline Author & Number of Cases or Information on Cases in the Literature \\
\hline Kumar (1993) & $1(\mathrm{G}-10)$ \\
\hline Tussie (1993) & 1 (Cairns Group) \\
\hline Ricupero (1999) & $\begin{array}{l}\text { The author does not conduct case studies, but provides historical information on the Cairns Group and on the Group of } \\
\text { Developing Countries. }\end{array}$ \\
\hline Narlikar (2003) & $\begin{array}{l}6 \text { (Informal Group, G-10, Café au Lait, Cairns Group, and Friends of Services Group) and some non-detailed information on other } \\
\text { coalitions. }\end{array}$ \\
\hline $\begin{array}{l}\text { Narlikar and } \\
\text { Tussie (2004) }\end{array}$ & $1(\mathrm{G}-20)$ \\
\hline $\begin{array}{l}\text { Narlikar and } \\
\text { Odell (2006) }\end{array}$ & 1 (The Like-Minded Group) \\
\hline $\begin{array}{l}\text { Odell and Sell } \\
(2006)\end{array}$ & 1 (Coalition on Intellectual Property and Public Health) \\
\hline Singh (2006) & The author surveys the literature, presenting a table with information on 10 coalitions. \\
\hline Lee $(2007)$ & 1 (The Africa Group) \\
\hline $\begin{array}{l}\text { Onuki and } \\
\text { Konishi Paulo } \\
(2007)\end{array}$ & $\begin{array}{l}\text { The authors do not conduct case studies, but map } 35 \text { coalitions and } 4 \text { regional agreements, providing information on them in a } \\
\text { table. }\end{array}$ \\
\hline $\begin{array}{l}\text { Hoda and Gulati } \\
(2008)\end{array}$ & 3 (Cairns Group, G-20, and G-33) \\
\hline Yu III (2008) & The author does not conduct case studies, but a policy-oriented paper with a table with information on 13 coalitions. \\
\hline Patel (2008) & The author does not conduct case studies, but presents a table with information on 25 coalitions. \\
\hline $\begin{array}{l}\text { Narlikar and } \\
\text { Tussie (2009) }\end{array}$ & $1(\mathrm{G}-20)$ \\
\hline
\end{tabular}

In our study, a "case" refers to interstate coalitions that bargain in the GATT/WTO. When a coalition adopts different positions during GATT or WTO negotiations, we consider each position of the coalition as a separate case. For instance, the Cairns Group put the defense of agricultural liberalization on the Uruguay Round agenda, with an intermediate position between the proposals of the United States and the European Community (EC). After the Blair House Agreement in November 1992, which took place between the United States and the EC, the group reduced their bargaining power because the world's two major trading powers agreed on their positions. In sum, the Cairns Group is considered a success at the beginning of the Uruguay Round and a failure after November 1992. The dispute over intellectual property rights also went through two phases. First, developing countries led by Brazil and India sought to block the inclusion of the intellectual-property-rights issue in the Uruguay Round but failed due to the United States' coercive action. In the Doha Round in 2001, a similar set of countries obtained a successful outcome. The later round stated that the issue of public health had to be prioritized above the profits of multinational companies (see more about this case below).

Some approaches break down the boundaries between case studies and quantitative analysis. The meta-analysis proposed in this paper is an attempt to unify the two approaches. It aggregates individual cases drawn from several studies into a single database 
for statistical analysis. Similar to a literature review, meta-analysis surveys the literature, treating individual case studies as units of observation for a larger project (Gerring 2007, 26). However, meta-analysis is more systematic than a literature review. It not only points to new avenues of research but also allows for greater generalization.

Specialized knowledge about a case can generate data of higher quality and greater detail, uncovering causal mechanisms and providing hypotheses that were not proposed in preceding theoretical analysis. Confirmation of the findings and generalizations from case studies can be achieved through analysis with a medium or large $N$. On some topics, there are many obstacles carrying quantitative research. Data compiled by large groups at universities or national and international agencies are restricted to easily measurable information or to data of direct interest to these institutions. These data do not always coincide with the problems to be solved. The high financial cost and the time consumed by building a case - such as fieldwork, document collection and review, and in-depth interviews - hinder the work of individual researchers or even a large group who want to generalize from case studies. Given the difficulty of comparing data obtained from these cases studies, it is also difficult to assess the generality of their findings.

In this paper, we increased our $N$ through the aggregation of qualitative data obtained from case studies to test hypotheses generated by these individual researchers. This methodology shows that case studies can be an important step in scientific enterprise. As Poteet and Ostrom argue: "This shift from a reliance on case studies to synthetic analyses parallels developments in any scientific enterprise. The challenges faced in making this shift affect empirical research about all topics without readily available data" (Poteet and Ostrom 2008, 177). The lack of comparative studies with medium or large $N$ limits the accumulation of knowledge about international coalitions in GATT/WTO negotiations. This obstacle affects the strategy of countries, which do not know what kinds of alliances lead them either to success or failure. Thus, comparative research with a broader focus would increase the confidence of policymakers on the types of coalitions they should build to succeed in GATT/WTO negotiations. Despite the advantages of our meta-analysis, we also turned to qualitative case studies aiming at investigating nuanced causal mechanisms that we could not isolate statistically.

\section{The Coding of Variables}

In reality, successes and failures are typically continuous variables, not dichotomous ones, since one rarely fails or succeeds completely. Most GATT/WTO bargaining coalitions have some demands that are not met. Thus, outcomes realistically should lie on a continuum of success and failure. However, establishing accurate criteria for determining 
the degree of either coalitional success or failure would make our analysis too complex. For analytical purposes, we grant success to coalitions that achieved most of their goals and failure to groups that have achieved either few or none of their goals.

Although it is impossible to say with certainty that a coalition has been successful or has failed in its initial objectives, the literature on the subject gives us a good criterion to analyze the main outcomes involving international coalitions. The state of knowledge prior to our research is the backbone of our undertaking (Ragin 2007; 2008). Our meta-analysis design offers the advantage of being easier to replicate than detailed qualitative case studies. The replication procedure can be carried out by including new cases, changing the operationalization of variables, or examining a different sampling of cases (for instance, focusing on other international institution rather than the GATT/WTO). Although we can estimate net effects better than the previous literature, we also need to go back to case studies to identify causal mechanisms that we could not see in our statistical analysis. Thus, we try to balance generalization with a fine-grained analysis in this study.

Conceptually, successes or failures are calibrated by looking at the balance of successes and failures (Baldwin 1985, chapter 7; Edelstein 2004, 58-59;) of GATT/WTO bargaining coalitions, according to their initial demands in the negotiations. Strictly, our dependent variable is not "measured" but "qualified" or "calibrated" (Ragin 2008, 71105), since neither successes nor failures can be measured accurately. We consider that the concepts of success and failure are linked to a long-term balance of benefits or losses obtained by the coalition. If the coalition did not achieve its goals despite the efforts of its members, we code it as an unsuccessful coalition. If it achieves a series of desired outcomes, it is considered a successful coalition. Obviously, the perception of the benefits obtained by a coalition is evaluated differently over time, because the goals of the coalition change. For this reason, more recent literature on the subject is to be favored over older analysis (Edelstein 2004). In the end, we found a surprising agreement among scholars in the way they evaluate success and failures.

As noted, the coding of both our dependent variable (success versus failure) and independent variable (scope) was guided by the specialized literature. However, we also sent e-mails to authors, read documents from the WTO, ${ }^{3}$ and conducted private interviews in Geneva, Washington, DC, and São Paulo to complement our information and to determine if we were proceeding correctly with our coding.

As some readers might have already realized, the coding of our independent variables was more straightforward than that of our dependent variable. Below, we outline how our variables were operationalized. 


\section{Dependent Variable}

- $\underline{\text { Success }}$ is based on a survey of the literature on the benefits gained by the coalition or by the fact that the coalition avoided critical losses.

- Failure is based on a survey of the literature on the drawback of the coalition or by the fact that the coalition did not prevent critical losses.

\section{Independent Variable 1: Coalition size}

- Coalition size is calibrated by the number of participants identified at the time of coalition formation.

\section{Independent Variable 2: Scope}

- Issue-based coalitions address only one theme in the negotiations.

- Broad-based coalitions negotiate two or more themes.

\section{Concepts and Case Selection}

Concepts are important for at least two reasons: they define the main categories of a given work and allow researchers to have both an explicit common language and a better case selection. If someone does not agree with a definition, at least he or she can criticize it if it is explained, so it is important to make concepts explicit. With operationalized concepts, we also can select cases that properly fit our sample (Goertz 2006; Sartori 1970).

In our research, international coalition is the main concept to be explained. More specifically, we wish to understand the role of "minimally institutionalized coalitions." To fit this definition, the coalition should be defined with relative clarity: its goals, its core members when the coalition was formed, and its successes and failures in terms of obtaining benefits in GATT/WTO negotiations. By analyzing minimally institutionalized coalitions, we differentiate this concept from informal meetings (a meeting between negotiators from different countries to exchange information and eventually cooperate). Our definition is also broader than the notion of formal or written coalitions, in which there is a formal act to establish the coalition.

The decision to select only minimally institutionalized coalitions in the GATT/WTO limits our sample of cases. In making this choice, we have reduced the danger of conceptual stretching (Collier and Mahon, Jr. 1993; Goertz 2006; Sartori 1970). Conceptual stretching occurs when concepts are defined in an extremely "permissive" or "vague" way to be applied to a larger number of cases. Consequently, one ends up comparing "incomparable" cases.

Our conceptual choice makes our research more reliable in terms of access to information. However, by choosing minimally institutionalized coalitions, there is always the 
possibility of identifying only groups that survived longer in GATT/WTO negotiations, because it is difficult to observe coalitions that failed early in these processes. Moreover, generalizations drawn from this study only apply to the population of cases defined by our core concept. For example, informal meetings and informal groups do not necessarily present the same behavior or outcomes as we are investigating in this study. Generalizations made here cannot be automatically applied to other international institutions (such as the UN, the World Bank, and the IMF), because different institutional rules stimulate different state behaviors.

As noted, our dependent variable (success versus failure) is difficult to calibrate. However, concepts central to political science (such as power) should not be overlooked just because there are no appropriate methodological tools to deal with them. Since these concepts are important to our discipline, we must continue looking for more accurate ways to measure these variables.

When analyzing a particular governmental policy, one of the first outcomes we want to know is whether they were successful or unsuccessful. From the policy standpoint, it is more important to know whether such a coalition is successful than to analyze how it is formed. If one concludes that the coalition is an ineffective tool to achieve gains in negotiations, perhaps one should not form coalitions in the first place. Therefore, one should look for other, more efficient tools.

Regarding the generalizability of our tests, since there are few cases of coalitions that fit our sample, our methodology suggests a "particular generalization" (Gaddis 2002; Wendt 2001). The concept of "particular generalization" implies that we can make general comments on existing structures. Since we know that a change in the process in a given period of time can create a new structure, our forecasting ability is very limited (Gaddis 2002 , 66). Consequently, we do not claim that future coalitions in the WTO will follow the same pattern found in this study. Although our sample is larger than previous ones in the literature, it still does not leave us confident enough to make predictions about the future behavior of GATT/WTO coalitions. However, by seeking to observe the entire population of existing cases of minimally institutionalized coalitions in GATT/WTO negotiations, our methodology provides a good explanation of the immediate past.

\section{Empirical Analysis}

The majority of the literature suggests that issue-based coalitions are more likely to succeed in GATT/WTO negotiations than broad-based coalitions. To test this claim, we sampled 31 coalitions in GATT/WTO negotiations. Out of 31 coalitions, 19 were classified as issue-based and 12 as broad-based. Among the 19 issue-based coalitions, we observed 
12 successes and seven failures. Among the 12 broad-based coalitions, we only observed five successes and seven failures (see Figure 1).

Figure 1. Graphical representation of a contingency table

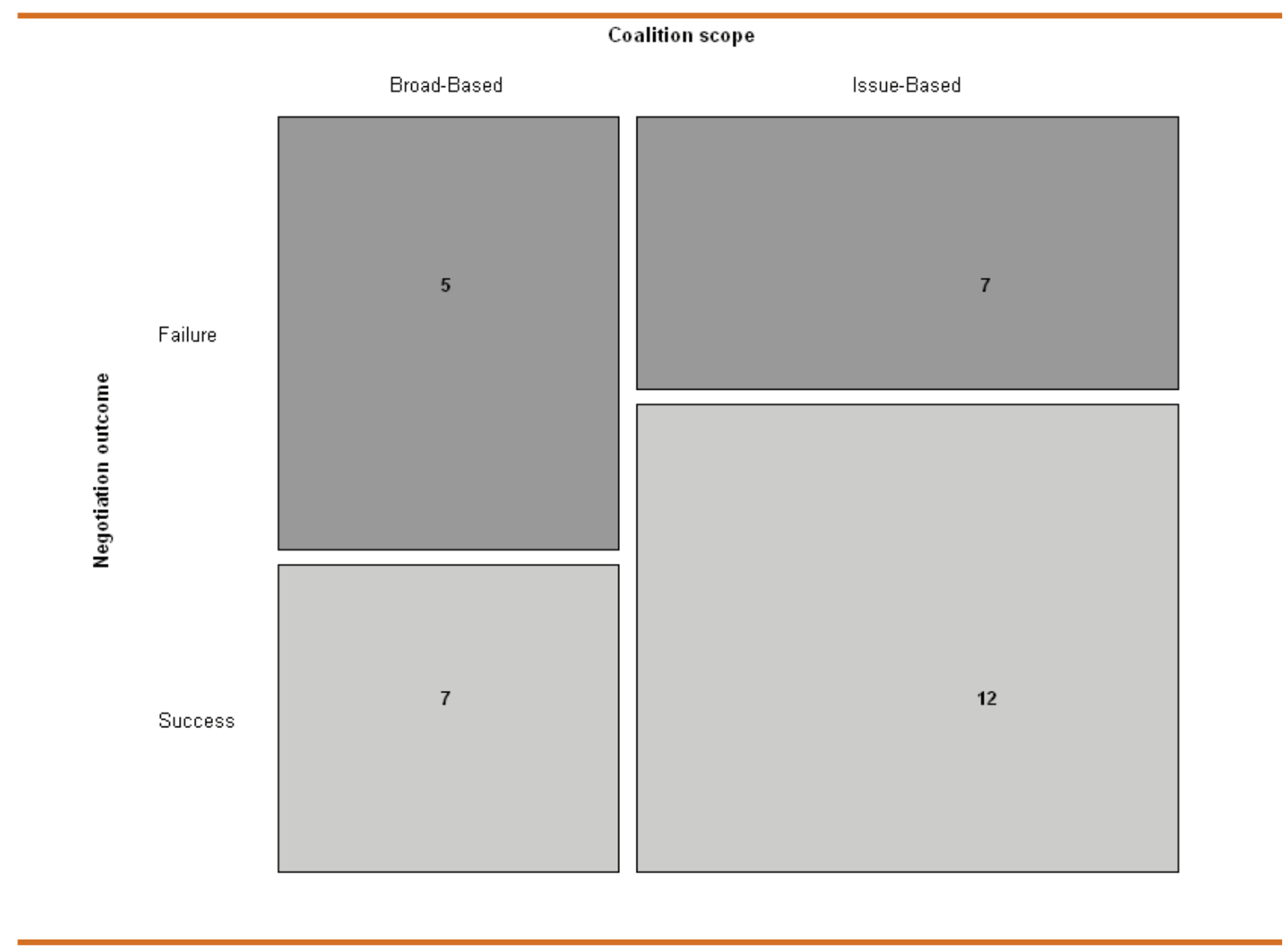

To formally test the claim that issued-based coalitions are more likely than broadbased groups to succeed, we have to compare the following conditional probabilities:

$\theta_{0}=\operatorname{PR}\left(y_{i}=1 \mid x_{i}=0\right)$

where $\theta_{0} \theta_{0}$ is the probability of success when the coalition $i i$ is broad-based, and $x_{i}=1 x_{i}=1$ means that the coalition $i i$ is broad-based;

$\theta_{1}=\operatorname{Pr}\left(y_{i}=1 \mid x_{i}=1\right)$,

where $\theta_{1} \theta_{1}$ is the probability of success when the coalition is issue-based, and $x_{i}=1$ $x_{i}=1$ means that the coalition $i$ i is broad-based.

The Maximum Likelihood Estimators (MLE) of these proportions are $\bar{\theta}_{0}=\frac{5}{5+7}=0.41 \bar{\theta}_{0}=\frac{5}{5+7}=0.41$ and $\bar{\theta}_{1}=\frac{12}{12+7}=0.63 \bar{\theta}_{1}=\frac{12}{12+7}=0.63$ respectively. These equations suggest that issue-based coalitions are more likely than broadbased coalitions to succeed in GATT/WTO negotiations. However, we have to determine if the difference is statistically significant. Since the sample is small, we cannot use an $X^{2}$ $X^{2}$ test, because this test does not perform well when there are few cases in each cell of 
a $2 \times 22 \times 2$ matrix (Jackman 2009). Sekhon (2005) argues that in cases like this, a $2 \times 2$ $2 \times 2$ Bayesian matrix may be a better option. Thus, to test our hypothesis we rely on the Bayesian approach: a $2 \times 22 \times 2$ Bayesian matrix and Bayesian probit regression.

Bayesian inference is now growing in popularity in the social sciences, and we refer readers interested in the subject to basic references in the area (Gelman and Hill 2007; Gelman et al. 2004; Gill 2007; Jackman 2009).

Bayesian analysis requires that we provide a prior probability distribution. Prior distributions can be seen as reflecting prior knowledge of the researcher (Gill 2007) or as a regularization tool in estimations that helps to establish the model (Gelman and Shalizi 2010). In this paper, we decided to use a Beta $(1,1)$ as our prior distribution. The Beta $(1,1)$ is equivalent to a uniform distribution. By assuming a uniform distribution, we let our estimation to be driven mainly by the data and less by our weakly informative prior knowledge. Moreover, this is a conjugated distribution, which is analytically convenient for our analysis. Conjugated distributions are distributions where, given a likelihood function, the posterior and prior distributions are in the same family, making it easy to derive the posterior distribution analytically.

Assuming that data are conditionally independent and identically distributed (i.i.d.), $\theta_{0} \theta_{1} \theta_{j} \sim \operatorname{Beta}(6,8) j=1,0 \theta_{0} \theta_{1} \theta_{j} \sim \operatorname{Beta}(6,8) j=1,0$ the posterior densities are $\theta_{0} \sim \operatorname{Beta}(6,8) \theta_{0} \sim \operatorname{Beta}(6,8)$, and $\theta_{1} \theta_{1}$ is a $\operatorname{Beta}(13,8) \operatorname{Beta}(13,8)$. Using Monte Carlo simulation, ${ }^{4}$ we computed the posterior probability that $\theta_{1}-\theta_{0}>0 \theta_{1}-\theta_{0}>0$, which it is at 0.87 . This result brings more confidence about the difference in the probability of success between issue-based and broad-based coalitions claimed by the literature.

The result for the scope of the coalition does not take into consideration the coalition size. However, in this section we are simply showing our most interesting results related to the specialized literature, since our small sample size does not allow us to have enough degrees of freedom to analyze all our variables simultaneously.

According to the literature on collective action, we would expect that, the bigger the coalitions, the higher the coordination costs, which may make them less likely to succeed (Olson 1965). However, we can also hypothesize that bigger coalitions have more power, since they have more GATT/WTO members supporting them (Narlikar 2003).

Again, it would be difficult to assess the uncertainty of a regression using frequentist methods, since we do not have a large enough sample to rely on asymptotic results. Bayesian inference does not have this problem, since the posterior density is in itself the quantification of our uncertainty and does not depend on asymptotic results (Gill 2007). Using a Bayesian probit model, we fit a model with scope and the log of coalition size as our predictors. Figure 2 shows the coefficients, as well as the uncertainties of our estimates. 
Figure 2. Bayesian probit regression coefficients with 95\% and 90\% significance*

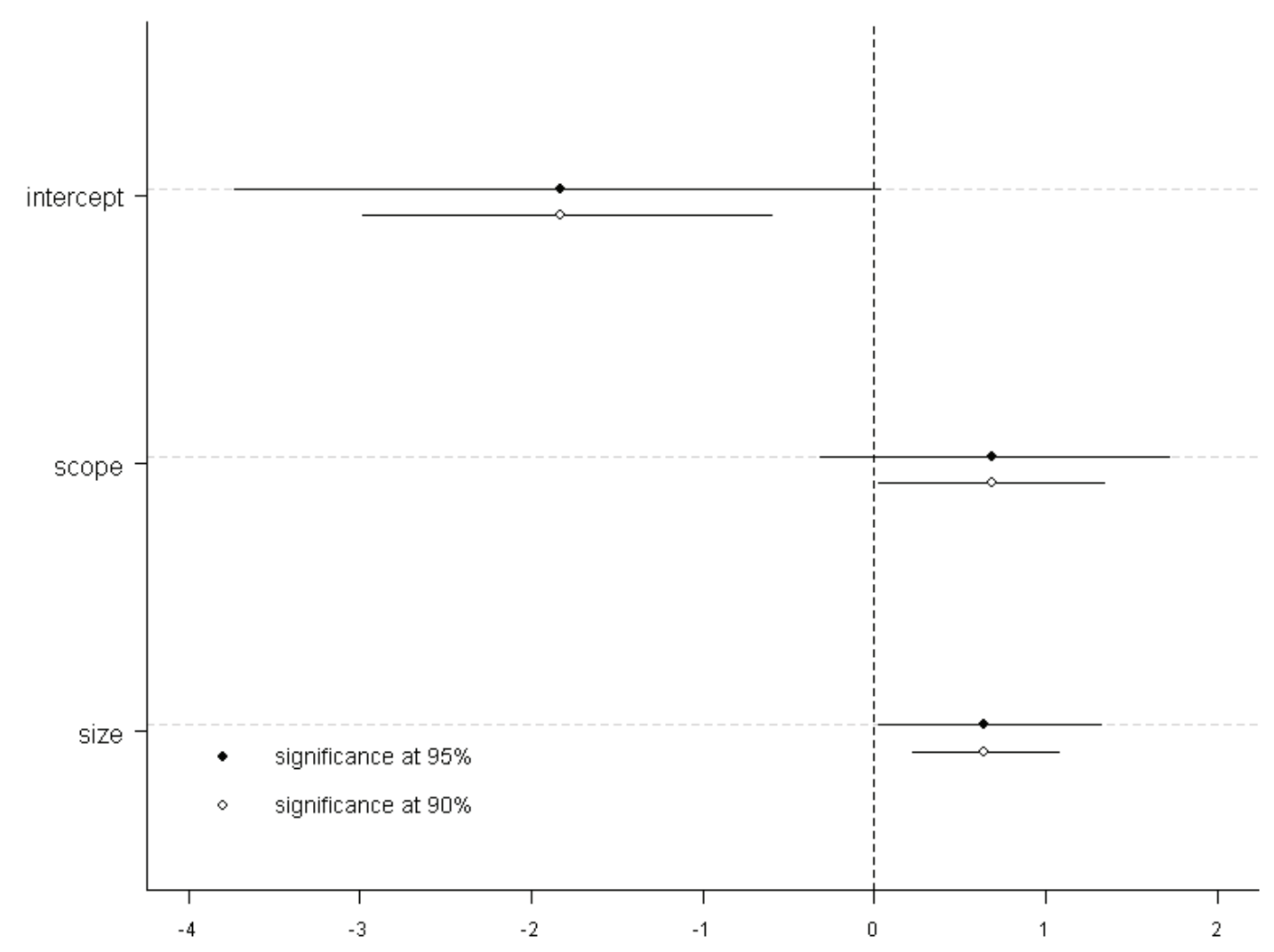

As shown in Figure 2, with our sample size we found that the probability of the predictive effect of scope being higher than zero is 0.900 .90 and the predictive effect of the log of coalition size being higher than zero is 0.9750 .975 . Using the mean of the posterior distribution of the coefficients as a point estimate, the effect of the log of coalition size is 0.640 .64 and the effect of scope is 0.670 .67 . Roughly speaking, this means that a difference of 0.10 .1 in the log of the number of countries participating in a coalition corresponds to no more than a positive difference of 0.100 .10 in the probability of succeeding at GATT/WTO negotiations. In other words, if a coalition has ten members and increases its participation to, say, 3030 members, the maximum effect of this increase is about 1010 percentage points in the probability of success. By the same token, by changing from broad-based to issued-based coalitions, we have a maximum predictive effect of 1010 percentage point in the probability of a coalition succeeding.

Thus, we have fair evidence that issue-based coalitions are more likely to succeed in the GATT/WTO negotiations. ${ }^{5}$ Moreover, we are more confident that coalition size

* Scope (issue-based) is significant only at the $90 \%$ level, while the log of coalition size is significant at the $95 \%$ level 
matters for the outcome of the negotiations (see Figure 3), and contrary to the argument about coordination costs, bringing more support to a given coalition has a predictive effect, which is quite important.

Figure 3. Marginal effect of the log of coalition size on the probability of success

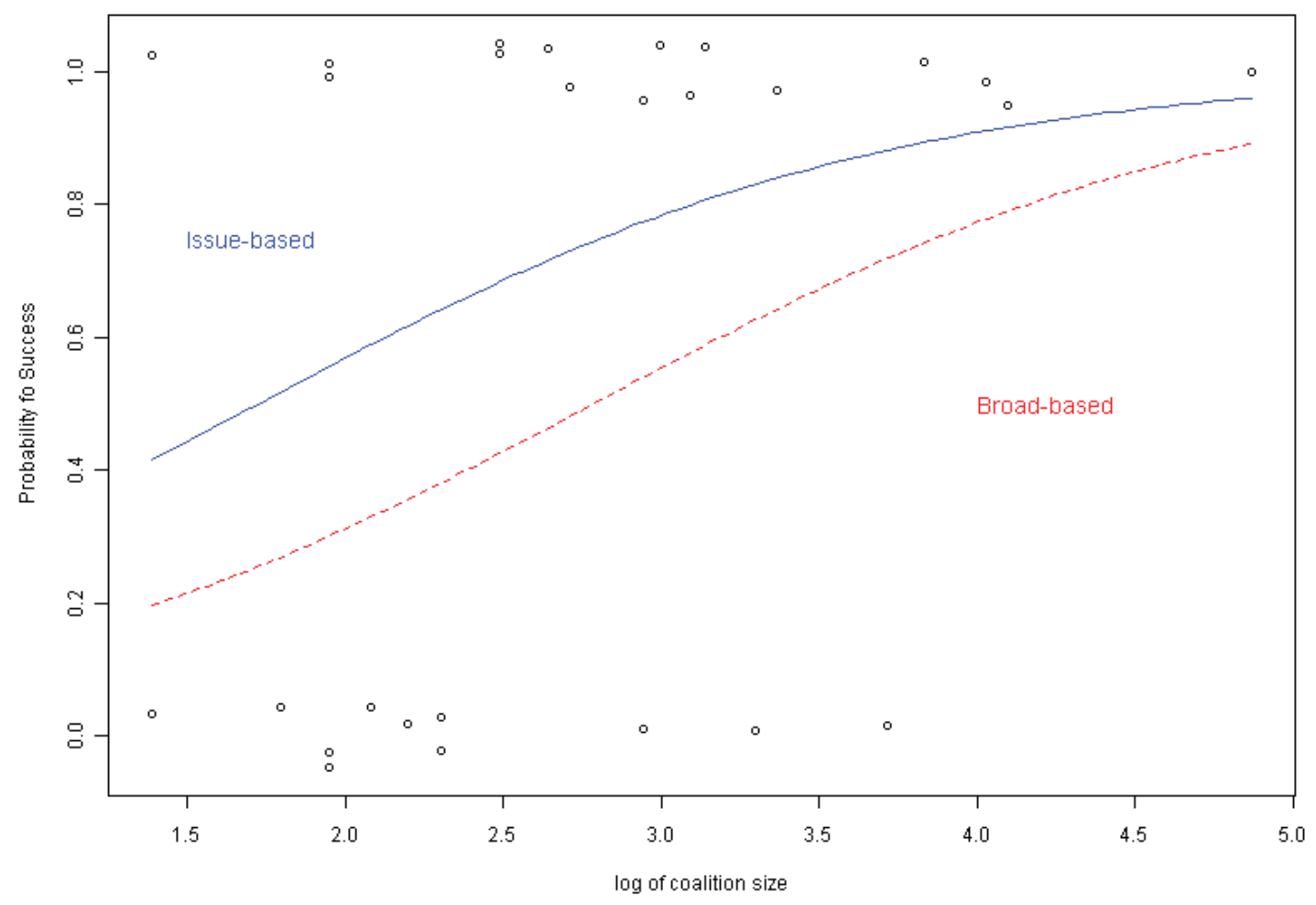

In Figure 3, we can see that most coalitions with comparatively large numbers (in lighter grey) resulted in successful outcomes. On the other hand, most coalitions with few members (in darker grey) had unsuccessful outcomes. In this sense, as explained in the paragraph above, numbers matter in GATT/WTO negotiations, and contrary to the intuition provided by the collective action literature, bigger is better.

However, we are not content to simply state that larger coalitions are more successful on average. Perhaps we are overestimating our results, since many countries might join larger coalitions because they believe (or know) that these coalitions tend to be more successful. Since the GATT and the WTO are consensus-based organizations, it seems less surprising that a given position becomes stronger as the number of coalition members approaches the number of the GATT/WTO members. By joining larger coalitions, states might guarantee that at least some of their demands will be taken into consideration. To further investigate this idea, we used a within-case study design to unravel possible causal 
mechanisms that could not be fully understood based solely on our statistical analysis. Therefore, in the next section we investigate a topic of great importance to GATT/WTO negotiations: the dispute over pharmaceutical patents. As the literature on coalitions in general is still in its infancy, we chose an area of inquiry (intellectual property rights) that has already been heavily debated and focused on the G-10 at the Uruguay Round (19861994) and the Public Health Coalition at the beginning of the Doha Round (2001-).

\section{The Dispute over Pharmaceutical Patents}

In this section, we analyze the dispute over pharmaceutical patents and focus on the conflict at GATT/WTO negotiations. State actors play a central role in this study (Drezner 2007) because the GATT/WTO only allows states as formal members. However, we are aware that multinational companies and NGOs have been growing rapidly on the international scene since the end of the Second World War both in terms of numbers and visibility (Haufler 1993). Negotiations over the creation and maintenance of international institutions are also restricted by the conditions and domestic policies of the states participating in these forums.

We first focus on the pressure the U.S. exerted in the 1980s on its long-term trade partners (e.g., Brazil and India) to adopt strict and universal intellectual-property-rights rules, which provoked the creation of G-10. Second, we analyze a case related to the same topic in which developing countries obtained significant gains during the 2001 Doha Conference held in Doha, Qatar, through the formation of the Public Health Coalition.

We selected these two cases in a within-case study design for both empirical and methodological reasons (George and Bennett 2004; Gerring 2007). The intellectual-property-rights dispute is an important and much debated topic both in the Uruguay Round and in the Doha Round. In our first case, a large broad-based developing-country coalition (G-10) failed to sustain its position against a smaller but stronger developed-country coalition (Quad) during the Uruguay Round. Both the G-10 and Quad negotiated intellectual property rights among other issues. In our second case, a large issue-based developing-country coalition (Public Health Coalition) was successful in defending its position against the United States.

What is the logic behind such different outcomes involving large coalitions? Do message framings pushed by coalitions influence the outcomes in GATT/WTO negotiations? Are these message framings related to an issue or broad-based coalition?

Explaining these puzzles helps us elucidate our quantitative findings. We argue that message framings adopted by those two different coalitions (G-10 and Public Health Coalition) influenced the attractiveness of the position advanced by those groups. Our causal 
mechanism suggests that, based on a favorable context and on a good strategy, coalitions can put forward a successful framing to defend their positions. The more convincing the framing, the better are the chances of coalitions keeping a large number of followers and supporters. Coalitions with a large number of participants are normally more successful because GATT/WTO negotiations are based on consensus. Countries are pressed to agree with the majority, since they can lose prestige or be subjected to later informal retaliation if they stand alone. Unless those countries have a strong position in the negotiations, they will probably align with large coalitions in order to have at least some of their demands met.

\section{The Uruguay Round and the Creation of the TRIPS}

In the mid-1980s, the United States was concerned about its relative economic decline (Evans 1989; Gilpin 1987; Kennedy 1987), which encouraged the hardening of U.S. foreign policy with respect to long-time trading partners. That decade was marked by radical technological change and the acceleration of economic globalization, when the U.S. began to pay more attention to internal pressures from the high-tech sector, who was seeking more stringent measures to maintain its interests and to expand its activities to external markets (Basso 2000, 160; Vaitsos 1989).

After 1984, the U.S. government resorted to more aggressive policies to assertively defend its economic interests (Cepaluni 2005, 2006; Evans 1989). With this strategy, the United States employed anti-protectionist international trade policies in favor of its domestic competitive sectors, such as the steel and the automobile industry. While advocating openness, the United States also sponsored trade regulations in areas where its products were less competitive, as in the case of pharmaceutical industry. Both Japan and the newly-industrialized countries — such as Brazil, South Korea and India - were the main target of these U.S. aggressive policies.

The pressures of the United States Trade Representative (USTR) hardened the negotiations for the creation of the WTO and intensified bilateral actions against countries that hindered the goals of the United States. ${ }^{6}$ At the multilateral level, U.S. foreign policy aimed to include the rights of patent-holders in the GATT by replacing the national freedom of application of standards and rules of property-rights protection - provided by the Paris Convention for the Protection of Industrial Property of 1883 - , and adopting stricter rules and standards for all contracting parties (Arslanian and Lyrio 1995; Cepaluni 2005, 2006).

In response to the U.S. proposal, some developing countries, especially India and Brazil, suggested that the discussion about the ownership of patents should be the responsibility of the World Intellectual Property Organization (WIPO). However, the United 
States, with the support of the European Community, not only managed to transform the GATT into the main international forum for discussion and regulation of the subject but also in 1990 managed to secure approval of a final text of the TRIPS group that was more similar to the world-class protection advocated by the Americans than to the proposals made by developing countries (Arslanian and Lyrio 1995).

According to Drahos (2003), when the Quad, a coalition formed by the United States, the European Union, Japan, and Canada, reached a consensus on the agenda of the GATT/WTO, the margin of maneuver for developing countries shrank. The creation of the Quad followed a straightforward logic. The United States and Canada agreed on broad principles for the negotiations. Later, they traded with the European Union and Japan on more specific topics. Finally, they began to argue that developing nations should adopt intellectual property standards similar to those adopted by the developed world (Braithwaite 2004, 17).

One reason for the weakness of developing countries' political opposition came from the fact that they could not sustain a coherent proposal that contemplated such a diverse group of countries. The opposition came from a coalition of developing countries, in which Brazil and India played a prominent role. Such a coalition, known as the G-10 (Argentina, Cuba, Egypt, India, Nicaragua, Nigeria, Peru, Tanzania, Yugoslavia, and Brazil), was composed of countries with diverse interests. The position of the G-10 was based on a complex and divergent set of arguments. It would have included on the agenda issues that had been traditionally handled by other agencies due to questions around the lack of analytical skills and experience in negotiating similar issues as well as the asymmetric nature of the benefits of liberalization (Abreu 2001, 93).

During the negotiations, India, Argentina and other developing countries gradually began to distance themselves from the Brazilian positions. In 1989, the position of the G-10 was already showing signs of lack of cohesion, mainly because of the polarization of the negotiations on textiles and TRIPS (Ibid., 94). It was heavily debated whether the issue of intellectual property should be negotiated in the GATT or in the WIPO. Developing countries, especially Brazil and India, initially resisted the U.S. proposal to insert into the GATT/WTO an international regime of intellectual property rights. However, as the Indian opposition weakened, the position of the developed countries prevailed (Ibid.).

Shukla $(2002,65)$, a former Indian representative to the GATT, and Sell and Prakash $(2004,159)$ agree that India and Brazil ended up accepting the extension of the GATT as the U.S. designed, because the USTR had been using unilateral measures under Section 301.

In 1988, the U.S. government imposed sanctions against Brazil in the case of pharmaceutical patents. Later, in May 1989, India was also the subject of retaliation. Consequently, 
the India-Brazil partnership weakened, resulting in a lack of coordination and mutual consultation that has left few traces of trust between the two countries.

The debt crisis of the 1980s also made it difficult for developing countries to present a more solid proposal. As indicated by Lima and Hirst, "two interrelated factors contributed to the deterioration of these conditions: a crisis of Third World debt and the 'hardening' of the negotiating context of economic issues between North and South" (Lima and Hirst 1997, 45). An example of this demobilization was the insertion of the TRIPS group into the GATT/WTO, despite initial opposition from developing countries like India and Brazil.

\section{The Public Health Coalition in Doha}

The Fourth Ministerial Conference in Doha in November 2001 contributed to weakening the traditional U.S. position, supported by many multinational pharmaceutical corporations to make intellectual-property-rights laws stricter. Developing countries (such as the African Group, Bangladesh, Barbados, Bolivia, Brazil, Cuba, the Dominican Republic, Ecuador, Haiti, Honduras, India, Indonesia, Jamaica, Pakistan, Paraguay, Philippines, Peru, Sri Lanka, Thailand, and Venezuela) built a Public Health Coalition (Abbott 2005, 326, fn 67) to defend against the WTO approving stricter intellectual-property-rights laws, because developing countries needed to produce and import medicines to combat the HIV/ AIDS epidemic. According to them, multinational pharmaceutical companies were making hefty profits out of the lives of HIV/AIDS patients, and governments and citizens in developing countries could not afford to pay the high prices of those basic medicines. Previously, the Third Ministerial Conference in Seattle in November 1999 had been considered a "fiasco" (Amorim 2000a, 2000b; Lamy 2000; Odell 2009; Thorstensen 2000/2001). In addition, bioterrorist threats after September 11, 2001, caused a change in U.S. foreign policy. In response to dozens of attacks using the anthrax virus, the United States Department of Health and Human Services announced that it would provide compulsory licenses for generic production of Bayer's ciprofloxacin if the company did not reduce the price of the drug, which weakened the strength of the United States with respect to compulsory licensing. It would not be surprising, therefore, to see the United States prioritize its security over intellectual property rights (Drezner 2007; Elbe 2006).

Expectations were generated around the declaration of the Fourth WTO Ministerial Conference held in Doha. This declaration, reiterating its "commitment to the TRIPS Agreement," states that "each Member has the right to grant compulsory licenses and the freedom to determine the grounds upon which such licenses are granted" (WTO 2001, 25). As Abbott points out, the Doha Declaration can be considered an agreement, because the WTO members consensually declared that they "agreed" with the text of the declaration 
(Abbott 2002). For the author, the legal language of the statement can be interpreted as a decision of all members in accordance to Article 9 of the agreement establishing the WTO. A decision by the WTO members is also an agreement under Article 31 of the Vienna Convention on the Law Treaties of 1969, which is equivalent to an interpretation of the TRIPS Agreement.

Politically, the Doha Declaration indicates that developing countries are more likely to achieve gains in international institutions than in bilateral negotiations with the United States because unilateralist policies are partially diluted by the rules agreed between the member states of these institutions (Lafer 1998, 28). Nevertheless, the TRIPS Agreement is "limited to the minimum standards of protection of intellectual property rights [....]. These standards, however, are modeled on western legal practice and are set at a level comparable to those in the developed countries" (Lanoszka 2003, 182).

The Public Health Coalition was able to send a proactive message that the lives of HIV patients were more important than the profits of multinational companies. This message supported the position of developing countries that were against stricter intellectual property rights. On the other hand, the G-10 in the Uruguay Round wanted to block the agenda of negotiations and bargaining on multiple topics. Its message was more negative in content and technical in meaning. The context of the negotiations was also less favorable to developing countries in the Uruguay Round. Many developing countries were in the middle of a serious debt crisis, and the United States was more determined to use unilateral trade measures. In the Doha Round, the threat to U.S. security and the possibility of offering compulsory licenses for ciprofloxacin softened the U.S. position. As said before, convincing frames are both dependent of strategies designed by coalition members and contingent on how others react to the messages put forth and defended by the coalition. These frames helped coalitions to get support (more members), hold together, and consequently be more successful in the GATT/WTO negotiations.

\section{Conclusion}

What types of coalitions are more successful in the negotiations of the GATT/WTO? To address this question, we tested two hypotheses: (1) issue-based coalitions are more successful than broad-based groups, and (2) coalitions with larger numbers of participants are more successful than the ones with smaller numbers.

The two hypotheses of this study were drawn from the literature. Our methodology was based on the aggregation of case studies to build a medium- $N$ database. Thanks to this procedure, we could apply a fresh methodological approach to the emerging literature on coalitions in GATT/WTO negotiations. Most authors who have researched coalitions 
in the GATT/WTO restricted themselves to a single or a few qualitative case studies. Others conducted historical research, mapping a slightly larger number of cases, but without any systematic analysis. By compiling cases in the same database, we obtained a higher $\mathrm{N}$ than elsewhere in the literature, which enabled us to conduct a statistical analysis.

We explained many of our methodological choices, leaving much work to be done by future research. We did our best to identify the current population of coalitions in GATT/ WTO negotiations, but our sample is still small from a statistical viewpoint. Obviously, this is a limitation of our study. To minimize this problem, we carefully chose and limited our independent variables, since more variables would drastically reduce our degrees of freedom.

Our dependent variable (success versus failure) was coded according to studies of cases written by individual researchers. Conceptually, we understood this variable to be a balance of successes or failures of a coalition over time. Our first independent variable (issue-based versus broad-based coalitions) was coded by a similar procedure. If an author wrote that one coalition failed or succeeded, our dependent variable was coded according his or her criteria. If an author said a coalition negotiated only one issue (e.g., intellectual property or agriculture) or had a broad agenda, we considered this coalition issue-based or broad-issue depending on the author's evaluation. Finally, our second independent variable (coalition size) was straightforwardly coded according to the number of members in the coalition at the moment of its formation.

We selected the largest possible number of cases, ideally approaching the existing population of coalitions in GATT/WTO negotiations. To do this, we created a working definition: "minimally institutionalized coalitions." This definition incorporated coalitions that clearly defined their goals, their main members, and their main successes and failures in terms of benefits in GATT/WTO negotiations.

A Bayesian statistical analysis showed that issue-based coalitions are on average more successful than groups with large demands (broad-based coalitions). Similarly, coalitions with larger numbers of members were shown to be more conducive to success in GATT/WTO negotiations than coalitions with smaller numbers. In this sense, if faced with the possibility of designing a coalition in GATT/WTO negotiations, countries should focus on issue-based coalitions with large numbers. Issue-based coalitions are more successful because these coalitions are more specialized; it is easier to have a division of labor among their members; they have an agenda-moving strategy instead of a blocking strategy adopted by many broad-based coalitions; and they normally present clearer messages. In GATT/WTO negotiations, coalition size matters because large coalitions have more power and legitimacy in those negotiations, since the number of members is finite and every country has the right to veto in the GATT/WTO. 
As we were afraid that states would join bigger coalitions because they know that these coalitions are more likely to succeed in GATT/WTO negotiations, we used a within-case study design to unravel possible causal mechanisms. We found that message framings are very important for coalitions to maintain their support. Messages put forward by issue-based coalitions tend to be easier to sell, since their messages are simpler. Broadbased coalitions normally present more complex and confrontational messages. In general, they want to block negotiations. Framing also depends on a favorable context. During the Uruguay Round, the developing-country debt and the link between the lack of patents and unfair trade provided a favorable context in which the United States could push its agenda. Thus, the G-10 was not able to maintain an internally consistent position. Before the Doha Declaration, the Public Health Coalition was able to link the defense of pharmaceutical patents with the protection of the lives of HIV patients in the developing world. This challenged the profit motive of multinational pharmaceutical companies. Thus, our causal narrative suggests that appropriate message framing put forth by issue-based coalitions helps to hold members together. With more legitimacy and with coalition members agreeing on a unified position, larger coalitions are more likely to succeed in GATT/WTO negotiations.

Revised by Sandra Gomes

Submitted in December 2011

Accepted in August 2012

\section{References}

Abbott, Frederick M. 2005. "The WTO Medicines Decision: World Pharmaceutical Trade and the Protection of Public Health". The American Journal of International Law, vol. 99, No. 2, pp. 317-358.

Abbott, Frederick M. 2002. "The Doha Declaration on the TRIPS Agreement and Public Health: Lighting a Dark Corner at the WTO". Journal of International Economic Law, vol. 5, no 2, pp. 469-505.

Abizadeh, Arash. 2005. "Does Collective Identity Presuppose an Other? On the Alleged Incoherence of Global Solidarity". American Political Science Review, vol. 99, n. 1, pp. 45-60.

Abreu, Marcelo de Paiva. 2001. "O Brasil, o GATT e a OMC: história e perspectivas". Política Externa, vol. 9, n 4 , pp. 89-119.

Amorim, Celso. 2000a. "A OMC e o Ano 2000". Carta Internacional, ano 8, nº 85.

Amorim, Celso. 2000b. "A OMC pós-Seattle". Política Externa, vol. 8, nº 4, pp. 100-115.

Arslanian, Regis Percy and Lyrio, Maurício Carvalho. 1995. "A reforma da lei de patentes no Brasil e as pressões norte-americanas na área de propriedade intelectual". Política Externa, vol. 4, $\mathrm{n}^{\mathrm{o}} 2$, pp. 3-12. 
Baldwin, David A. 1985. Economic Statecraft. Princeton, New Jersey: Princeton University Press.

Basso, Maristela. 2000. O Direito Internacional da Propriedade Intelectual. Porto Alegre: Livraria do Advogado Editora.

Bown, Chad P. 2004. "Trade Policy under the GATT/WTO: Empirical Evidence of the Equal Treatment Rule". The Canadian Journal of Economics / Revue canadienne d'Economique, vol. 37, No. 3, pp. 678-720.

Braithwaite, John. 2004. "Methods of Power for Development: Weapons of the Weak, Weapons of the Strong". Michigan Journal of International Law, vol. 26, No. 1, pp. 297-330.

Buchanan, James M. 1965. "An Economic Theory of Clubs". Economica, New Series, vol. 32, n 125, pp. 1-14.

Busch, Marc L. 2000. "Democracy, Consultation, and the Paneling of Disputes under GATT". Journal of Conflict Resolution, vol. 44, n. 4, pp. 425-446.

Busch, Marc L. 2007. "Overlapping Institutions, Forum Shopping, and Dispute Settlement in International Trade". International Organization, vol. 61, pp. 735-61.

Busch, Marc L. and Reinhardt, Eric. 2001. "Bargaining in the Shadow of the Law: Early Settlement in GATT/WTO Disputes”. Fordham International Law Journal, vol. 24, n. 1, pp. 158-172.

Busch, Marc L. and Reinhardt, Eric. 2006. "Three's a Crowd: Third Parties and WTO Dispute Settlement". World Politics, vol. 58, pp. 446-77.

Busch, Marc L. and Pelc, Krzysztof J. 2009. "Does the WTO Need a Permanent Body of Panelists?". Journal of International Economic Law, vol. 12, n. 3, 579-594.

Busch, Marc L., Reinhardt, Eric and Shaffer, Gregory. 2009. "Does legal capacity matter? A survey of WTO Members". World Trade Review, vol. 8, n. 4, pp: 559-577.

Cepaluni, Gabriel. 2006. Regime de Patentes: Brasil X Estados Unidos no Tabuleiro Internacional. São Paulo: Editora Aduaneiras/Lex Editora.

Cepaluni, Gabriel. 2005. "Regimes Internacionais e o Contencioso das Patentes para Medicamentos: Estratégias para Países em Desenvolvimento". Contexto Internacional, vol. 27, $\mathrm{n}^{\circ} 1$, pp. 51-99.

Cerny, Philip G. 1995. "Globalization and the Changing Logic of Collective Action". International Organization, vol. 49, n. 4, pp. 595-625.

Chamberlin, John. 1974. "Provision of Collective Goods as a Function of Group Size". The American Political Science Review, vol. 68, n. 2, pp. 707-716.

Charnovitz, Steve. 2001. "Rethinking WTO Trade Sanctions". The American Journal of International Law, vol. 95, n. 4, pp. 792-832.

Collier, David and Mahon, Jr., James. 1993. "Conceptual 'Stretching' Revisited: Adapting Categories in Comparative Analysis". The American Political Science Review, vol. 87, no. 4, pp. 845-855.

Cooper, Andrew F., Higgot, Richard A., and Nossal, Kim Richard. 1993. Relocating Middle Powers: Australia e Canada in a Changing World Order. Vancouver: UBCPress. 
Davis, Christina L. and Shirato, Yuki. 2007. "Firms, Governments, and WTO Adjudication: Japan's Selection of WTO Disputes". World Politics, vol. 59, pp. 274-313.

Davis, Christina L. and Bermeo, Sarah Blodgett. 2009. "Who Files? Developing Country Participation in GATT/WTO Adjudication". The Journal of Politics, vol. 71, n. 3, pp. 1033-1049.

Drahos, Peter. 2003. "When the Weak Bargain with the Strong: Negotiations in the World Trade Organization". International Negotiation, vol. 8, pp. 79-109.

Drezner, Daniel W. 2007. All Politics is Global. Princeton: Princeton University Press.

Edelstein, David M. 2004. "Occupational Hazards: Why Military Occupations Succeed or Fail". International Security, vol. 29, n. 1, pp. 49-91.

Elbe, Stefan. 2006. "Should HIV/AIDS be Securitized? The Ethical Dilemmas of Liking HIV/ AIDS and Security". International Studies Quarterly, 50, n pp. 119-144.

Esteban, Joan and Ray, Debraj. 2001. "Collective Action and the Group Size Paradox". American Political Science Review, vol. 95, n. 3, pp. 663-672.

Evans, Peter. 1989. "Declining Hegemony and Assertive Industrialization: U.S.-Brazil Conflicts in the Computer Industry". International Organization, vol. 43, No. 2, pp. 207-238.

Frohlich, Norman and Oppenheimer, Joe A. 1970. "I Get by with a Little Help from my Friends". World Politics, vol. 23, n. 1, pp. 104-120.

Gaddis, John Lewis. 2002. The Landscape of History: How Historians Map the Pas. Oxford: Oxford University Press.

Gelman, Andrew and Hill, Jennifer. 2007. Data Analysis Using Regression and Multilevel/ Hierarchical Model. Cambridge: Cambridge University Press.

Gelman, Andrew, Carlin, John B., Stern, Hal S., and Rubin, Donald B. 2009. Bayesian Data Analysis, $2^{\text {nd }}$ Edition. Chapman \& Hall/CRC.

Gelman, Andrew and Shalizi, Cosma. 2011. "Philosophy and the practice of Bayesian statistics in the social sciences". In: Harold Kincaid (ed.), Oxford Handbook of the Philosophy of the Social Sciences. Oxford University Press.

George, Alexander L. and Bennett, Andrew. 2004. "Case Studies and Theory Development in the Social Science". Cambridge, Massachusetts: MIT Press.

Gerring, John. 2007. Case Study Research: Principles and Practices. Cambridge: Cambridge University Press.

Gill, Jeff. 2007. Bayesian Methods: A Social and Behavioral Sciences Approach, $2^{\text {nd }}$ Edition. Chapman and Hall/CRC.

Gilpin, Robert. 1987. The Political Economy of International Relations. Princeton: Princeton University Press.

Goldstein, Judith L., Rivers, Douglas, and Tomz, Michael. 2007. "Institutions in International Relations: Understanding the Effects of the GATT and the WTO on World Trade". International Organization, vol. 61, pp. 37-67. 
Goertz, Gary. 2006. Social Science Concepts: A User's Guide. Princeton, New Jersey: Princeton University Press.

Greenhill, Brian. 2008. "Recognition and Collective Identity Formation in International Politics". European Journal of International Relations, vol. 14, pp. 343.

Haftel, Yoram Z. 2004. "From the Outside Looking In: The Effect of Trading Blocs on Trade Disputes in the GATT/WTO". International Studies Quarterly, vol. 48, 121-142.

Hamilton, Colleen and Whalley, John. 1989. "Coalitions in the Uruguay Round". Review of World Economics, vol. 125, n. 3, pp. 547-562.

Hamilton, Colleen and Whalley, John. 1988. "Coalitions in the Uruguay Round: The Extend, Pros and Cons of Developing Country Participation". NBER Working Paper Series, Working paper n. 2.751. Cambridge, National Bureau of Economic Research.

Hardin, Garrett. 1968. "The Tragedy of the Commons”. Science, vol. 162, pp. 1243-1248.

Hardin, Russell. 1982. Collective Action. Baltimore: John Hopkins University Press.

Haufler, Virginia. 1993. "Crossing the Boundary Between Public and Private: International Regimes and Non-State Actors". In: RITTBERGER, Volker (ed.), Regime Theory and International Relations, Oxford: Clarendon Press.

Higgott, Richard A. and Cooper, Andrew Fenton. 1990. "Middle Power Leadership and Coalition Building: Australia, the Cairns Group, and the Uruguay Round of Trade Negotiations". International Organization, vol. 44, $\mathrm{n}^{\circ}$ 4, pp. 589-632.

Jackman, Simon. 2009. Bayesian Analysis for the Social Sciences. New York: Wiley.

Kennedy, Paul. 1987. The Rise and Fall of Great Powers. New York: Vintage Books, 1987.

Kim, Moonhawk. 2008. "Costly Procedures: Divergent Effects of Legalization in the GATT/WTO Dispute Settlement Procedures". International Studies Quarterly, vol. 52, 657-686.

Lafer, Celso. 1998b. A OMC e a Regulamentação do Comércio Internacional: Uma Visão Brasileira. Porto Alegre: Livraria do Advogado Editora.

Lamy, Pascal. 2000. "Pos-Seattle: A Vision of Globalization and of the Challenges Ahead". Carta Internacional, $\mathrm{n}^{\circ} 85$.

Lanoszka, Anna. 2003. "The Global Politics of Intellectual Property Rights and Pharmaceutical Drug Policies in Developing Countries". International Political Science Review, vol. 24, n. 2, pp. 181-197.

Lima, Maria Regina Soares de and Hirst, Mônica. 1997. "O Brasil e os Estados Unidos: Dilemas e Desafios de uma Relação Complexa”. In: Gélson Fonseca Júnior and Sérgio H. N. de Castro. (eds.), Temas de Política Externa Brasileira II, vol. 2, 2a edição. São Paulo: Paz e Terra.

Mansfield, Edward D. and Reinhardt, Eric. 2003. "Multilateral Determinants of Regionalism: The Effects of GATT/WTO on the Formation of Preferential Trading Arrangements". International Organization, vol. 57, pp. 829-862. 
Mansfield, Edward D. and Reinhardt, Eric. 2008. "International Institutions and the Volatility of International Trade". International Organization, vol. 62, pp. 621-52.

Mcguire, Martin. 1974. "Group Size, Group Homogeneity, and the Agreement Provision of a Pure Public Good under Cournot Behavior". Public Choice, vol. 18, pp. 107-126.

Moon, Don. 2006. "Equality and Inequality in the WTO Dispute Settlement (DS) System: Analysis of the GATT/WTO Dispute Data". International Interactions, vol. 32, pp. 201-228.

Narlikar, Amrita. 2003. International Trade and Developing Countries: Bargaining Coalitions in the GATT and WTO. London: Routledge.

Narlikar, Amrita and Tussie, Diana. 2004. "The G20 at the Cancun Ministerial: Developing Countries and Their Evolving Coalitions in the WTO". World Economy, vol. 27, n. 7, pp. 947-966.

Odell, John S. 2009. "Breaking Deadlocks in International Institutional Negotiations: The WTO, Seattle, and Doha". International Studies Quarterly, vol. 53, n. 2, pp. 273-299.

Odell, John S. and Sell, Susan K. 2006. "Reframing the issue: the WTO coalition on intellectual property and public health, 2001". In: Odell, John S. (ed.), Negotiating Trade: Developing Countries in the WTO and NAFTA. Cambridge: Cambridge University Press.

Oliver, Pamela E. and Marwell, Gerald. 1988. "The Paradox of Group Size in Collective Action: A Theory of the Critical Mass II". American Sociological Review, vol. 53, n. 1, pp. 1-8.

Olson, Jr., Mancur. 1965. The Logic of Collective Action: Public Goods and the Theory of Groups, 1. ed. Harvard University Press.

Olson, Jr., Mancur. 1971. "Increasing the Incentives for International Cooperation". International Organization, vol. 25, $\mathrm{n}^{\circ}$ 4, pp. 866-874.

Olson, Jr., Mancur. 1982. The Rise and Decline of Nations: Economic Growth, Stagflation, and Social Rigidities. New Haven and London: Yale University Press.

Olson, Jr., Mancur and Zeckhauser, Richard. 1966. "An Economic Theory of Alliances”. The Review of Economics and Statistics, vol. 48, n 3, pp. 266-279.

Ostrom, Elinor. 2000. "Collective Action and the Evolution of Social Norms". The Journal of Economic Perspectives, vol. 14, n. 3, pp. 137-158.

Ostrom, Elinor. 1990. Governing the Commons: The Evolution of Institutions for Collective Action. Cambridge: Cambridge University Press.

Pecorino, Paul and Temimi, Akram. 2008. "The Group Size Paradox Revisited". Journal of Public Economic Theory, vol. 10, n. 5, pp. 785-799.

Pecorino, Paul. 2009. "Public Goods, Group Size, and the Degree of Rivalry". Public Choice, vol. 138, pp. 161-169.

Pelc, Krzysztof J. 2010. "Eluding efficiency: why do we not see more efficient breach at the WTO?" World Trade Review, 9, pp. 629-642. 
Poteete, Amy R. and Ostrom, Elinor. 2008. "Fifteen Years of Empirical Research on Collective Action in Natural Resource Management: Struggling to Built Large-N Databases Based on Qualitative Research". World Development, vol. 36, n 1, pp. 176-195.

Ragin, Charles C. 2007. Fuzzy-Set Social Science. Chicago and London: University of Chicago Press.

Ragin, Charles C. 2008. Redesigning Social Inquiry: Fuzzy Sets and Beyond. Chicago and London: University of Chicago Press.

Reinhardt, Eric. 2001. "Adjudication without Enforcement in GATT Disputes". Journal of Conflict Resolution, vol. 45 n. 2, pp. 174-195.

Riker, William H. 1970. "Reflections on Empires". In: Francis A. Beer. (ed.), Alliances: Latent War Communities in the Contemporary World. New York: Holt, Rinehart and Winston.

Riker, William H. 1962. The Theory of Political Coalitions. New Haven: Yale University Press.

Rose, Andrew K. 2004. "Do We Really Know That the WTO Increases Trade?" The American Economic Review, vol. 94, n. 1, pp. 98-114.

Rosendorff, Peter B. 2005. "Stability and Rigidity: Politics and Design of the WTO's Dispute Settlement Procedure”. American Political Science Review, vol. 99, n. 3, pp. 389-400.

Rothstein, Robert L. 1984. "Regime Creation by a Coalition of the Weak: Lessons from the NIEO and the Integrated Program for Commodities". International Studies Quarterly, vol. 28, n. 3, pp. 307-328.

Sartori, Giovanni. 1970. "Concept Misformation in Comparative Politics". American Political Science Review, vol. 64, n. 4, pp. 1033-1053.

Sekhon, Jasjeet S. 2005. "Making Inferences from $2 \times 2$ Tables: The Inadequacy of the Fisher Exact Test for Observational Data and a Principled Bayesian Alternative". Working Paper.

Sell, Susan K. and Prakash, Aseem. 2004. "Using Ideas Strategically: The Contest between Business and NGO Networks in Intellectual Property Rights". International Studies Quarterly, vol. 48, n. 1, pp. 143-175.

Shukla, S. P. 2002. "From the GATT to the WTO and Beyond". In: Nayyar, Deepak (ed.), Governing Globalization: Issues and Institutions. Oxford: Oxford University Press.

Smith, James. 2004. "Inequality in International Trade? Developing Countries and Institutional Change in WTO Dispute Settlement". Review of International Political Economy, vol. 11, n. 3, pp. 542-573.

Stanley, T. D. 2001. "Wheat from Chaff: Meta-Analysis as Quantitative Literature Review". Journal of Economic Perspectives, vol. 15, no 3, pp. 131-150.

Steinberg, Richard H. 2002. "In the Shadow of Law or Power? Consensus-Based Bargaining and Outcomes in the GATT/WTO". International Organization, vol. 56, n. 2, pp. 339-374.

Subramanian, Arvind and Wei, Shang-Jin. 2007. "The WTO promotes trade, strongly but unevenly". Journal of International Economics, vol. 72, pp. 151-175. 
Thorstensen, Vera. 2000/2001. "OMC: A Retomada dos Trabalhos após o Impasse de Seattle". Política Externa, vol. 9, n 3.

Tijmes-Lhl, Jaime. 2009. "Consensus and majority voting in the WTO". World Trade Review, vol. 8, n. 3, pp. 417-437.

Vaitsos, Constantine V. 1989. "Radical Technological Changes and the New 'Order' in the WorldEconomy”. The European Journal of Development Research, vol. 1, n. 1, pp. 60-84.

Wendt, Alexander. 2001. "Driving with the Rearview Mirror: On the Rational Science of Institutional Design". International Organization, vol. 55, n. 4, pp. 1019-1049.

Wendt, Alexander. 1999. Social Theory of International Politics. Cambridge: Cambridge University Press.

Wendt, Alexander. 1994. "Collective Identity Formation and the International State". American Political Science Review, vol. 88, n 2, pp. 384-396.

Wendt, Alexander. 1992. "Anarchy is What States Make of It: The Social Construction of Power Politics". International Organization, vol. 46, n. 2, pp. 391-425.

WTO. 2001. Doha Declarations. Available at: http://www.wto.org/english/res_e/booksp_e/ddec_e.pdf.

Wolfe, Robert. 2005. "See You in Geneva? Legal (Mis)Representations of the Trading System". European Journal of International Relations, vol. 11, n. 3, pp. 339-365.

Zangl, Bernhard. 2008. "Judicialization Matters! A Comparison of Dispute Settlement Under GATT and the WTO". International Studies Quarterly, vol. 52, pp. 825-854.

\section{Notes}

1 See http://www-rcf.usc.edu/ enn/.

2 Currently, we have a larger dataset on coalitions than the one found at the WTO website: http://www.wto.org/.

3 See "Groups in the Negotiations", 18 April 2011, available at http://www.wto.org/english/ tratop_e/dda_e/negotiating_groups_e.htm.

4 We ran 10,000 simulations.

5 Although Fisher's exact test and maximum likelihood estimates of probit regression do not produce a significant difference between the two types of coalitions.

6 As Evans points out $(1989,325)$, the target countries of Section 301 are not "just sinners against the free trade regime; they were successful rivals or potential rivals, guilty of using neomercantilist techniques to improve their position in the hierarchy of nations relative to that of 'fair players' such as the United States". 